\title{
Evidence for a time-dependent association between FOLR1 expression and survival from ovarian carcinoma: implications for clinical testing. An Ovarian Tumour Tissue Analysis consortium study
}

M Köbel $^{1}$, J Madore, ${ }^{2,3}$, S J Ramus ${ }^{4}$, B A Clarke ${ }^{5}$, P D P Pharoah ${ }^{6,7}$, S Deen ${ }^{8}$, D D Bowtell ${ }^{9,10,11}, \mathrm{~K}$ Odunsi $^{12}$, U Menon ${ }^{13}, \mathrm{C}$ Morrison $^{14}$, S Lele ${ }^{12,15}$, W Bshara ${ }^{14}$, L Sucheston $^{15}, \mathrm{M} \mathrm{W} \mathrm{Beckmann}{ }^{16}, \mathrm{~A}$ Hein ${ }^{16}, \mathrm{~F} \mathrm{C}$ Thiel $^{16}$, A Hartmann ${ }^{17}$, D L Wachter ${ }^{17}$, M S Anglesio ${ }^{2}$, E Høgdall $^{18,19}$, A Jensen ${ }^{18}$, C Høgdall $^{20}, \mathrm{~K}$ R Kalli ${ }^{21}, \mathrm{~B}$ L Fridley ${ }^{22}$, G L Keeney ${ }^{23}$, Z C Fogarty ${ }^{24}$, R A Vierkant ${ }^{24}$, S Liu ${ }^{25}$, S Cho ${ }^{1}$, G Nelson ${ }^{26}$, P Ghatage ${ }^{26}$, A Gentry-Maharaj ${ }^{13}$, S A Gayther ${ }^{4}$, E Benjamin ${ }^{27}$, M Widschwendter ${ }^{28}, \mathrm{M} \mathrm{P} \mathrm{Intermaggio}^{4}, \mathrm{~B}^{2}$ Rosen ${ }^{29}, \mathrm{M} \mathrm{O}$ Bernardini ${ }^{29}, \mathrm{H} \mathrm{Mackay}^{30}$, A Oza ${ }^{29}$, P Shaw ${ }^{29}$, M Jimenez-Linan ${ }^{31,32}, \mathrm{~K}$ E Driver ${ }^{7}$, J Alsop 7 , M Mack ${ }^{7}$, J M Koziak ${ }^{33}$, H Steed $^{34}$, C Ewanowich $^{35}$, A DeFazio ${ }^{36}$, G Chenevix-Trench ${ }^{37}$, S Fereday9, B Gao ${ }^{36}$, S E Johnatty ${ }^{37}$, J George ${ }^{9}$, L Galletta ${ }^{9}$, AOCS Study Group 9 , E L Goode ${ }^{38}$, S K Kjær ${ }^{18,20}$, D G Huntsman ${ }^{2,39}$, P A Fasching ${ }^{16,40}$, K B Moysich ${ }^{15}$, J D Brenton ${ }^{32,41,42,43}$ and L E Kelemen ${ }^{\star, 44}$

${ }^{1}$ Department of Pathology and Laboratory Medicine, University of Calgary, Foothills Medical Center, 140329 ST NW, Calgary, AB T2N 2T9, Canada; 'Department of Pathology and Laboratory Medicine, University of British Columbia, BC Cancer Agency, 600 West 10th Avenue, Vancouver, BC V5E 4E6, Canada; ${ }^{3}$ Melanoma Institute Australia, University of Sydney, Royal Prince Alfred Hospital, Gloucester House-level 3, Missenden Road, Camperdown, NSW 2050, Australia; ${ }^{4}$ Department of Preventive Medicine, Keck School of Medicine, USC/Norris Comprehensive Cancer Center, University of Southern California, Harlyne Norris Research Tower, 1450 Biggy Street, Office 2517G, Los Angeles, CA 90033, USA; ${ }^{5}$ Department of Laboratory Medicine and Pathobiology, Princess Margaret Cancer Centre, University of Toronto, 610 Univeristy Avenue, M-700, Toronto, ON M5T 2M9, Canada; ${ }^{6}$ Department of Public Health and Primary Care, University of Cambridge, Strangeways Research Laboratory, Worts Causeway, Cambridge CB1 8RN, UK; ${ }^{7}$ Department of Oncology, University of Cambridge, Strangeways Research Laboratory, Worts Causeway, Cambridge CB1 8RN, UK; ${ }^{8}$ Department of Histopathology, Queen's Medical Centre, Nottingham University Hospitals NHS Trust, Nottingham NG7 2UH, UK; ${ }^{9}$ Department of Cancer Genomics and Genetics, Peter MacCallum Cancer Centre, Locked Bag I, A'Beckett Street, East Melbourne, VIC 8006, Australia; ${ }^{10}$ Department of Biochemistry and Molecular Biology, University of Melbourne, 30 Flemington Road, Melbourne, VIC 3010, Australia; ${ }^{11}$ Sir Peter MacCallum Department of Oncology, University of Melbourne, 30 Flemington Road, Melbourne, VIC 3010, Australia; ${ }^{12}$ Department of Gynecological Oncology, Roswell Park Cancer Institute, Elm and Carlton Streets, Buffalo, NY 14263, USA; ${ }^{13}$ Gynaecological Cancer Research Centre, Department of Women's Cancer, Institute for Women's Health, University College London, Maple House 1st Floor, 149 Tottenham Court Road, London W1T 7DN, UK; ${ }^{14}$ Department of Pathology and Laboratory Medicine, Roswell Park Cancer Institute, Elm and Carlton Streets, Buffalo, NY 14263, USA; ${ }^{15}$ Department of Cancer Prevention and Control, Roswell Park Cancer Institute, Elm and Carlton Streets, Buffalo, NY 14263, USA; ${ }^{16}$ Department of Gynecology and 
Obstetrics, University Hospital Erlangen, Friedrich-Alexander University Erlangen-Nuremberg, Comprehensive Cancer Center Erlangen-EMN, Universitaetsstrasse 21-23, 91054 Erlangen, Germany; ${ }^{17}$ Institute of Pathology, University Hospital Erlangen, Friedrich-Alexander University Erlangen-Nuremberg, Comprehensive Cancer Center Erlangen-EMN, Krankenhausstrasse 8-10, 91054 Erlangen, Germany; ${ }^{18}$ Department of Virus, Lifestyle and Genes, Danish Cancer Society Research Center, Strandboulevarden 49, DK-2100 Copenhagen, $\varnothing$, Denmark; ${ }^{19}$ Department of Pathology, Herlev Hospital, University of Copenhagen, Herlev Ringvej 75, DK-2370 Herlev, Denmark; ${ }^{20}$ The Juliane Marie Center, Department of Obstetrics and Gynecology, Rigshospitalet, University of Copenhagen, Blegdamsvej 9, DK-2100 Copenhagen, Ø, Denmark; ${ }^{21}$ Department of Medical Oncology, Mayo Clinic, 200 First Street SW, Charlton 6, Rochester, MN 55905, USA; ${ }^{22}$ Department of Biostatistics, University of Kansas Medical Center, 3901 Rainbow Boulevard, Kansas City, KS 66160, USA; ${ }^{23}$ Department of Laboratory Medicine and Pathology, Division of Anatomic Pathology, Mayo Clinic, 200 First Street SW, Stabile 13, Rochester, MN 55905, USA; ${ }^{24}$ Department of Health Sciences Research, Division of Biomedical Statistics and Informatics, Mayo Clinic, 200 First Street SW, Charlton 6, Rochester, MN 55905, USA; ${ }^{25}$ Anatomic Pathology Research Laboratory, Calgary Laboratory Services, Foothills Medical Center, 140329 ST NW, Calgary, AB T2N 2T9, Canada; ${ }^{26}$ Department of Obstetrics and Gynecology, Division of Oncology, Tom Baker Cancer Centre, University of Calgary, Foothills Medical Center, 140329 ST NW, Calgary, AB T2N 2T9, Canada; ${ }^{27}$ Department of Pathology, Cancer Institute, University College London, Maple House, 149 Tottenham Court Road, London WC1E 6JJ, UK; ${ }^{28}$ Department of Women's Cancer, UCL EGA Institute for Womeńs Health, University College London, 74 Huntley Street, London WC1E 6AU, UK; ${ }^{29}$ Department of Obstetrics and Gynecology, University of Toronto, Princess Margaret Cancer Centre, 610 University Avenue, M-700, Toronto, ON M5T 2M9, Canada; ${ }^{30}$ Department of Medicine, Division of Medical Oncology, University of Toronto, Princess Margaret Hospital, 610 University Avenue, Toronto, ON M5G 2M9, Canada; ${ }^{31}$ Department of Pathology, Addenbrooke's Hospital, Cambridge University Hospital NHS Foundation Trust, Hills Road, Cambridge CB2 0QQ, UK; ${ }^{32}$ National Institute for Health Research Cambridge Biomedical Research Centre, Cambridge CB2 2QQ, UK; ${ }^{33}$ Department of Population Health Research, Alberta Health Services-Cancer Care, 2210 2nd Street SW, Calgary, AB, T2S 3C3, Canada; ${ }^{34}$ Department of Obstetrics and Gynecology, Division of Gynecologic Oncology, Royal Alexandra Hospital, 10240 Kingsway Ave, Edmonton, AB T5H 3V9, Canada; ${ }^{35}$ Department of Laboratory Medicine and Pathology, Royal Alexandra Hospital, 10240 Kingsway Ave, Edmonton, AB T5H 3V9, Canada; ${ }^{36}$ Department of Gynaecological Oncology and Westmead Institute for Cancer Research, University of Sydney at Westmead Millennium Institute, Westmead Hospital, Westmead, NSW 2145, Australia; ${ }^{37}$ Genetics and Computational Biology Department, QIMR Berghofer Medical Research Institute, 300 Herston Road, Herston, QLD,4006, Australia; ${ }^{38}$ Department of Health Sciences Research, Division of Epidemiology, Mayo Clinic, 200 First Street SW Charlton 6, Rochester, MN 55905, USA; ${ }^{39}$ Centre For Translational and Applied Genomics, British Columbia Cancer Agency, 600 West 10th Avenue, Vancouver, BC V5Z 4E6, Canada; ${ }^{40}$ Department of Medicine, Division of Hematology and Oncology, David Geffen School of Medicine, University of California at Los Angeles, Los Angeles, CA 90095, USA; ${ }^{41}$ Department of Oncology, University of Cambridge, Hutchison/MRC Research Centre, Hills Road, Cambridge CB2 OXZ, UK; ${ }^{42}$ Cancer Research UK Cambridge Institute, University of Cambridge, Li Ka Shing Centre, Robinson Way, Cambridge CB2 ORE, UK; ${ }^{43}$ Cambridge Experimental Cancer Medicine Centre, Cambridge CB2 ORE, UK; ${ }^{44}$ Department of Public Health Sciences, Medical University of South Carolina and Hollings Cancer Center, 135 Cannon Street, Charleston, SC 29425, USA

Background: Folate receptor 1 (FOLR1) is expressed in the majority of ovarian carcinomas (OvCa), making it an attractive target for therapy. However, clinical trials testing anti-FOLR1 therapies in OvCa show mixed results and require better understanding of the prognostic relevance of FOLR1 expression. We conducted a large study evaluating FOLR1 expression with survival in different histological types of OvCa.

Methods: Tissue microarrays composed of tumour samples from 2801 patients in the Ovarian Tumour Tissue Analysis (OTTA) consortium were assessed for FOLR1 expression by centralised immunohistochemistry. We estimated associations for overall (OS) and progression-free (PFS) survival using adjusted Cox regression models. High-grade serous ovarian carcinomas (HGSC) from The Cancer Genome Atlas (TCGA) were evaluated independently for association between FOLR1 mRNA upregulation and survival.

Results: FOLR1 expression ranged from $76 \%$ in HGSC to $11 \%$ in mucinous carcinomas in OTTA. For HGSC, the association between FOLR1 expression and OS changed significantly during the years following diagnosis in OTTA $\left(P_{\text {interaction }}=0.01\right.$, $N=1422)$ and TCGA ( $P_{\text {interaction }}=0.01, N=485$ ). In OTTA, particularly for FIGO stage I/II tumours, patients with FOLR1-positive HGSC showed increased OS during the first 2 years only (hazard ratio $=0.44,95 \%$ confidence interval $=0.20-0.96$ ) and patients with FOLR1-positive clear cell carcinomas (CCC) showed decreased PFS independent of follow-up time $(\mathrm{HR}=1.89,95 \% \mathrm{Cl}=1.10$ 3.25, $N=259$ ). In TCGA, FOLR1 mRNA upregulation in HGSC was also associated with increased OS during the first 2 years following diagnosis irrespective of tumour stage (HR: 0.48, 95\% Cl: 0.25-0.94).

Conclusions: FOLR1-positive HGSC tumours were associated with an increased OS in the first 2 years following diagnosis. Patients with FOLR1-negative, poor prognosis HGSC would be unlikely to benefit from anti-FOLR1 therapies. In contrast, a decreased PFS interval was observed for FOLR1-positive CCC. The clinical efficacy of FOLR1-targeted interventions should therefore be evaluated according to histology, stage and time following diagnosis. 
Folate receptor 1 (FOLR1) is a member of the folate receptor family that has restricted expression in normal epithelial cells, but is reported to be highly expressed in various tumours of epithelial origin including the majority of ovarian carcinomas (Kelemen et al, 2005; Parker et al, 2005; Chen et al, 2012; Crane et al, 2012; Despierre et al, 2013; O'Shannessy et al, 2013). FOLR1 has high affinity for binding folic acid (Parker et al, 2005). Because folate is essential for DNA synthesis and one-carbon transfer, it has been hypothesised that FOLR1 might confer a growth advantage to the tumour by modulating folate uptake (Kane et al, 1988) or generating regulatory signals (Miotti et al, 2000). However, others showed that FOLR1 was not the major transport route for intracellular accumulation of physiological folates or anti-folates in various cell lines including the IGROV-1 ovarian cancer cells (Kamen and Smith, 2012), thereby disputing the theory of FOLR1medicated tumour uptake of folate for proliferation.

Studies evaluating the prognostic value of FOLR1 expression in ovarian carcinoma have produced conflicting results. Chen et al (2012) reported that FOLR1 mRNA upregulation was an unfavourable prognostic marker in a study of 91 serous ovarian carcinomas. In two studies that used immunohistochemistry (IHC), women with FOLR1 expressing ovarian carcinomas had no difference in survival rate: RR $0.86,95 \%$ CI $0.57-1.31, P=0.49$, $N=186$ (Kalli et al, 2008) and RR 0.80, 95\% CI 0.5-1.1, $P=0.2$, $N=361$ (Crane et al, 2012). These two studies contained a mixture of all histological types, which may mask associations when both the marker prevalence (Kalli et al, 2008) and survival rates (Kobel et al, 2008) differ between the histological types.

The prognostic significance of FOLR1 may have therapeutic relevance. FOLR1 selectivity, affinity and restricted tissue distribution has christened it as a universal target for exploitation (van Dam et al, 2011) for therapy or imaging of solid tumours (Leamon and Reddy, 2004) or circulating tumour cells (He et al, 2008). Different treatment modalities have been proposed including folic acid-conjugated toxins that bind FOLR1 and release the toxin upon internalisation to kill tumour cells (Kelemen, 2006), and antitumour immune-based therapies that enhance the body's natural immunity against tumour cells (Knutson et al, 2006). However, clinical trials testing therapies against FOLR1 in ovarian carcinoma have produced mixed results. For example, farletuzumab (Konner et al, 2010; Spannuth et al, 2010; Armstrong et al, 2013) is a humanised monoclonal antibody against FOLR1, which was shown to mediate antibody-dependent cellular cytotoxicity and complement-dependent cytotoxicity and to inhibit cell growth of a Chinese hamster ovary cell line transfected with FOLR1 when grown in low-folate medium (Ebel et al, 2007), although subsequent studies showed it minimally altered cell growth in cell lines naturally expressing FOLR1, including IGROV-1 ovarian cancer cells (Kamen and Smith, 2012). The results from a phase III clinical trial (NCT00849667) found that farletuzumab in combination with carboplatin and taxane did not meet the study's primary end point of progression-free survival (PFS), and analyses are ongoing in patient subsets (Walters et al, 2013). More recently, a phase II clinical trial reported longer median PFS among 100 selected patients with recurrent platinum-resistant ovarian carcinoma who were treated with a combination of vintafolide, a folic acid-desacetylvinblastine conjugate that binds to the folate receptor, and pegylated liposomal doxorubicin (PLD) compared with 49 patients who received PLD alone (5.0 vs 2.7 months PFS, respectively; $P=0.03$ ) (Naumann et al, 2013). The drug was particularly effective in patients diffusely positive for FOLR1. No difference in overall survival (OS) was detected, although the trial was not powered to detect a statistical difference (Naumann et al, 2013).

To address discrepant findings and to improve upon previous study designs, we evaluated tumours from 2801 patients from the Ovarian Tumour Tissue Analysis (OTTA) consortium to assess the prevalence of FOLR1 protein expression and to associate prevalence with survival for the different histological types separately. The goal of the OTTA consortium is to combine tissue microarray resources to overcome the limitations of prognostic studies associated with small sample sizes. We also utilised data from The Cancer Genome Atlas (TCGA) as a large, independent sample to evaluate these associations.

\section{MATERIALS AND METHODS}

Patients. Twelve individual studies comprising 2801 patients participating in the OTTA consortium were included for FOLR1 IHC expression analysis. Several of these studies also participated in previous OTTA IHC analyses (Kobel et al, 2013; Sieh et al, 2013) and were assessed using a biomarker-assisted review of patients' slides for histological classification (Kobel et al, 2013). Informed consent was obtained from patients in seven of 12 studies. For the Alberta Ovarian Tumor Types study (AOV), Calgary Serous Carcinoma study (CAL), Nottingham Ovarian Cancer study (NOT), Toronto Ovarian Cancer study (TOC) and British Columbia Cancer Agency study (VAN), the institutional research ethics boards waived the need to obtain consent and all local human research investigations committees approved each study. Key demographical and clinical data on the patients were merged into one common data set that was checked for consistency and completeness, and discrepancies were addressed with individual study investigators.

Immunohistochemistry (IHC). Centralised IHC was performed on a Leica Bond Max platform (Leica Microsystems, Wetzlar, Germany). The submitted glass slides from tissue microarrays were subjected to heat-induced antigen retrieval for $20 \mathrm{~min}$ using the Leica Epitope Retrieval Solution 2. Slides were incubated with the FOLR1 mouse monoclonal antibody from Novocastra (Leica Microsystems) clone BN3.2 (catalogue \#NCL-F-FRalpha) for $15 \mathrm{~min}$ at a $1: 50$ dilution.

Scoring. Two observers (MK, JM) scored the FOLR1 staining. We combined a measure of the intensity, extent and subcellular localisation into a five-tier scoring system: absent or weak staining, strong staining of $1-50 \%$ of tumour cells irrespective of subcellular localisation, strong staining of $>50 \%$ of tumour cells with membranous localisation (with no penalisation for accompanying weak cytoplasmic staining), strong staining of 50-95\% of tumour cells with cytoplasmic staining (and membranous staining still present) and strong staining of $>95 \%$ of tumour cells with cytoplasmic staining (Figure 1). The inter-observer reproducibility of the five-tier IHC scoring system between the two observers was evaluated in a subset of 183 patients and was high (weighted Cohen's kappa $=0.91)$. We also compared the five-tier IHC scores for FOLR1 obtained using the BN3.2 antibody with FOLR1 mRNA expression data derived by RNA sequencing from a subset of 36 patients (Shah et al, 2009). The IHC scores correlated reasonably well with the mRNA expression values (Pearson $r=0.77$ ).

The Cancer Genome Atlas (TCGA). We downloaded publiclyavailable data from 563 serous ovarian carcinomas from TCGA (The Cancer Genome Atlas Research Network, 2011) using the cBIOPortal for Cancer Genomics (Cerami et al, 2012) to assess prevalence of FOLR1 mRNA expression in tumour relative to normal tissue (fallopian tube) and to evaluate expression with survival outcomes as described below. Gene expression in TCGA was evaluated using the Agilent $244 \mathrm{~K}$ Custom Gene Expression G4502A_07 (Santa Clara, CA, USA) assayed at the University of North Carolina and expressed as fold change between tumour and normal tissue on the $\log 2$ scale (The Cancer Genome Atlas Research Network, 2011). 

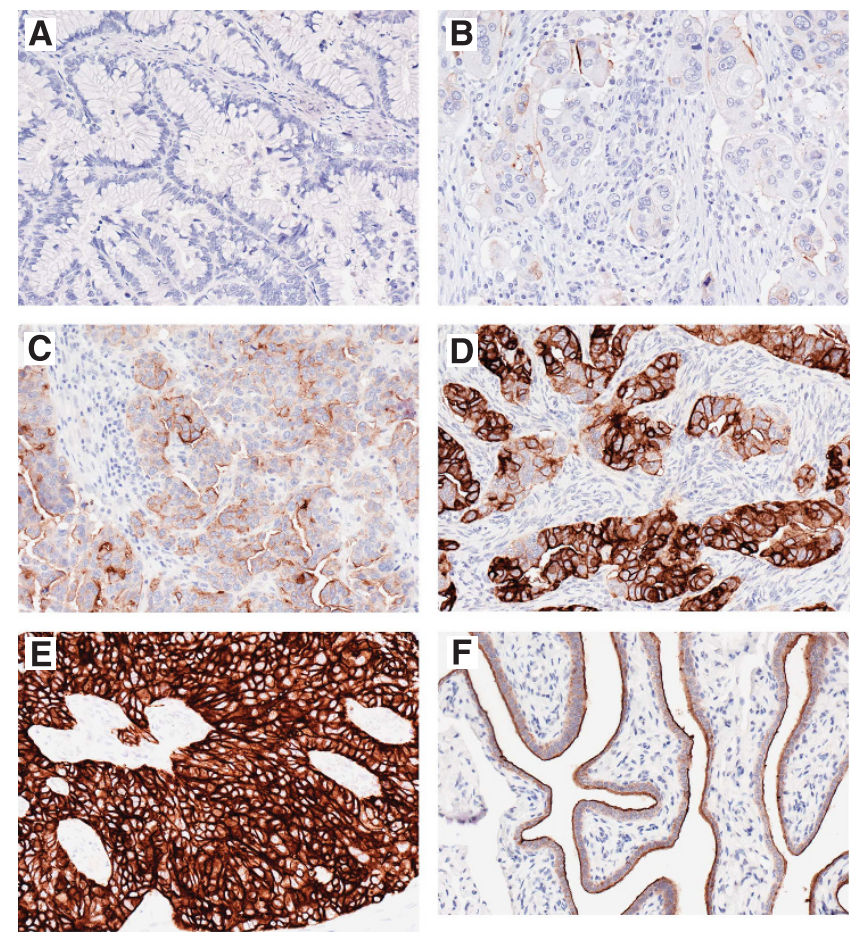

Figure 1. Immunohistochemical staining of FOLR1. (A) No staining in a mucinous carcinoma. (B) Strong staining of $1-50 \%$ of tumour cells in a high-grade serous carcinoma. (C) Strong staining of $>50 \%$ of tumour cells with predominant membranous localisation in a high-grade serous carcinoma. (D) Strong staining of 50-90\% of tumour cells with

cytoplasmic staining (and membranous staining still present) in a highgrade serous carcinoma. (E) Strong staining of $>90 \%$ of tumour cells with cytoplasmic staining in a high-grade serous carcinoma. (F) Strong staining of $>50 \%$ of epithelial cells with predominant membranous localisation in normal fallopian tube.

Statistical analysis. We assessed 2801 patients from the OTTA consortium for prevalence of FOLR1 expression and included the five main histological types: high-grade serous carcinoma (HGSC), low-grade serous carcinoma (LGSC), mucinous carcinoma (MC), endometrioid carcinoma (EC) and clear cell carcinoma (CCC). Patients with absent or weak FOLR1 staining were recorded as negative, whereas all the other FOLR1 staining patterns were considered positive results. In separate analyses using the larger sample size of HGSC in OTTA, we visually inspected Kaplan-Meier survival curves and evaluated statistical associations between patients using the five-tier scoring system for FOLR1 and also with different combinations of scores (e.g., strong staining of $>50 \%$ of tumour cells with cytoplasmic or membranous staining $v s$ all other staining patterns) stratified by the FIGO (International Federation of Obstetricians and Gynaecologists) stage. None of these alternate combinations produced associations that were materially different from the positive/ negative staining comparison (data not shown).

The Cox proportional hazard model was used to estimate hazard ratios (HRs) and 95\% confidence intervals (CIs) between positive/negative categories of FOLR1 and OS or PFS stratified by histological type. In the OTTA consortium, OS was defined as death from any cause after ovarian carcinoma diagnosis and PFS was defined as survival without disease progression or recurrence determined by radiological, serological or clinical evidence or death from any cause, whichever came first. Stage at diagnosis was determined using the cancer registry and/or FIGO stage information from each site (SEER guidelines: http://seer.cancer.gov/) and categorised as FIGO stage I/II (localised and regional) and FIGO stage III/IV (distant). Because time from diagnosis to study entry was variable, we allowed for left truncation with time at risk starting on the date of diagnosis and time under observation beginning at the time of study entry. Analyses were right censored at 5 years after ovarian carcinoma diagnosis in order to reduce the number of non-ovarian carcinoma-related deaths. The proportional hazard assumption was evaluated with standard diagnostic methods, including likelihood ratio tests comparing models with and without terms that modelled covariates as a function of followup time on the natural logarithmic scale (Hosmer and Lameshow, 1999). Final models were fitted using Cox regression stratified by study to correct for violations of the proportional hazard assumption and adjusted for potential confounding with age at diagnosis ( $<70$ or $\geqslant 70$ years), FIGO tumour stage (I/II, III/IV or missing) and presence of residual disease at primary surgery (macroscopic, no macroscopic or missing). An interaction term between the aforementioned covariates and follow-up time was included, where necessary, to improve model fit. In addition, we considered models separately by the FIGO tumour stage. Data for regression analyses were available for 2636 patients following the exclusion of patients with missing vital status $(N=13)$, missing time from diagnosis to study entry $(N=66)$, missing follow-up time $(N=43)$, missing FIGO stage $(N=84$, excluded for stagestratified analyses only) and patients with study entry $>5$ years from diagnosis $(N=43)$.

Using TCGA data, FOLR1 mRNA information was available for 485 patients and we defined mRNA upregulation as $>1$ s.d. from the mean on the $\log 2$ scale. Associations with OS and PFS were evaluated with follow-up time as described above and adjusted for the FIGO tumour stage (I/II, III/IV or missing) and presence of residual disease at primary surgery (macroscopic, no macroscopic or missing). Separate models also adjusted for platinum therapy sensitivity (resistant, sensitive, too early or missing) and treatment response (complete response, partial response, progressive disease, stable disease or missing). Age at diagnosis was not available in TCGA.

Statistical tests were two sided and were implemented with SAS (version 9.1, SAS Institute, Cary, NC, USA) and Stata/SE (version 13.1, StataCorp, College Station, TX, USA). The study followed the REMARK guidelines (McShane et al, 2005).

\section{RESULTS}

Study and patient characteristics. Table 1 describes the participating studies and methods of patient ascertainment and histological review. Table 2 lists the 2801 women with ovarian carcinoma that were included in the FOLR1 expression prevalence analysis, stratified by study and histological type. As expected, women with HGSC were older, were diagnosed with high tumour stage and were more likely to have macroscopic residual disease and shorter OS and PFS compared with women with EC (Table 3). Women with EC had the best prognosis.

FOLR1 expression across histological types. We observed differences in FOLR1 expression by histological type: patients with tumours of LGSC, MC, EC or CCC histology were more likely to have absent or weak FOLR1 staining compared with patients with HGSC tumours (Table 3). FOLR1-positive expression was seen in 1149 out of 1507 patients (76.2\%) with HGSC, 45 out of 91 patients (49.5\%) with LGSC and 141 out of 446 patients (31.6\%) with CCC. Normal fallopian tube tissue was included as a control on the tissue microarrays and was FOLR1-positive in 8 out of 8 samples (100\%) (Figure 1).

Association between FOLR1 expression in HGSC tumours and survival. In OTTA, there were no statistically significant associations with OS or PFS for HGSC overall or when evaluated separately by the FIGO stage; however, the association between FOLR1 expression and OS changed when stratified by follow-up 
Table 1. Description of 12 participating studies in OTTA

\begin{tabular}{|c|c|c|c|c|c|}
\hline Study & $\begin{array}{l}\text { Study } \\
\text { abbreviation }\end{array}$ & $\begin{array}{l}\text { Study } \\
\text { location }\end{array}$ & $\begin{array}{l}\text { Recruitment } \\
\text { period }\end{array}$ & $\begin{array}{l}\text { Ascertainment of patients and } \\
\text { clinical data }\end{array}$ & Pathology data and review \\
\hline $\begin{array}{l}\text { Australian Ovarian Cancer } \\
\text { Study (Merritt et al, 2008) }\end{array}$ & $A O C$ & Australia & $2002-2006$ & $\begin{array}{l}\text { Treatment centers throughout Australia; } \\
\text { cancer registries serving Queensland, } \\
\text { South and Western Australia; longitudinal } \\
\text { follow-up through regular review of } \\
\text { medical records }\end{array}$ & $\begin{array}{l}\text { Pathology reports and } \\
\text { diagnostic slides reviewed by } \\
\text { a panel of gynaecologic } \\
\text { pathologists }\end{array}$ \\
\hline $\begin{array}{l}\text { Alberta Ovarian Tumor } \\
\text { Types Study (Kelemen } \\
\text { et al, 2013) }\end{array}$ & AOV & $\begin{array}{l}\text { Alberta, } \\
\text { Canada }\end{array}$ & 1998-2009 & $\begin{array}{l}\text { Population-based Alberta Cancer } \\
\text { Registry. Annual updates are performed } \\
\text { for vital statistics }\end{array}$ & $\begin{array}{l}\text { Pathology reports and } \\
\text { histological slides reviewed by } \\
\text { gynaecologic pathologist }\end{array}$ \\
\hline $\begin{array}{l}\text { Bavarian Ovarian Cancer } \\
\text { Study (Hein et al, 2013) }\end{array}$ & BAV & $\begin{array}{l}\text { Southeast } \\
\text { Germany }\end{array}$ & $2002-2006$ & $\begin{array}{l}\text { Gynecologic Oncology Center at the } \\
\text { Comprehensive Cancer Center } \\
\text { Erlangen-Nuremberg }\end{array}$ & $\begin{array}{l}\text { Centralised review of } \\
\text { pathology reports and } \\
\text { histological slides for all cases } \\
\text { by study pathologists }\end{array}$ \\
\hline $\begin{array}{l}\text { Calgary Serous Carcinoma } \\
\text { Study (Bromley et al, 2012) }\end{array}$ & CAL & $\begin{array}{l}\text { Calgary, } \\
\text { Canada }\end{array}$ & 2003-2007 & $\begin{array}{l}\text { Hospital-based retrospective } \\
\text { observational study }\end{array}$ & $\begin{array}{l}\text { Histological review of all slides } \\
\text { by study pathologist } \\
\text { supported by centralised } \\
\text { biomarker analysis }\end{array}$ \\
\hline $\begin{array}{l}\text { Novel risk factors and } \\
\text { potential early detection } \\
\text { markers for the Ovarian } \\
\text { Cancer Study (Lo-Ciganic } \\
\text { et al, 2012) }\end{array}$ & $\mathrm{HOP}$ & $\begin{array}{l}\text { Western PA, } \\
\text { Northeastern } \\
\text { Ohio, } \\
\text { Western NY, } \\
\text { USA }\end{array}$ & 2003-2009 & $\begin{array}{l}\text { Hospital registries and active surveillance } \\
\text { of medical practices in three catchment } \\
\text { areas }\end{array}$ & $\begin{array}{l}\text { Medical chart review for } \\
\text { all cases }\end{array}$ \\
\hline $\begin{array}{l}\text { Malignant Ovarian Cancer } \\
\text { Study (Glud et al, 2004; } \\
\text { Soegaard et al, 2007) }\end{array}$ & MAL & Denmark & 1994-1999 & $\begin{array}{l}\text { Gynecological departments in } \\
\text { Copenhagen, Frederiksberg and seven } \\
\text { surrounding counties }\end{array}$ & $\begin{array}{l}\text { Pathology reports reviewed } \\
\text { for all cases and histological } \\
\text { slides reviewed for } 30 \% \text { by } \\
\text { gynaecologic pathologist }\end{array}$ \\
\hline $\begin{array}{l}\text { Mayo Clinic Ovarian } \\
\text { Cancer Study (Goode et al, } \\
\text { 2011) }\end{array}$ & $M A Y+M A C$ & $\begin{array}{l}\text { Northcentral } \\
\text { USA }\end{array}$ & $2000-2009$ & $\begin{array}{l}\text { Mayo Clinic medical records and State } \\
\text { death certificates }\end{array}$ & $\begin{array}{l}\text { Review by Mayo Clinic } \\
\text { gynaecologic pathologists } \\
\text { supported by centralised } \\
\text { biomarker analysis }\end{array}$ \\
\hline $\begin{array}{l}\text { Nottingham Study } \\
\text { (Williams et al, 2012) }\end{array}$ & NOT & UK & $1991-2008$ & Hospital records and Trent cancer registry & $\begin{array}{l}\text { Pathology reports reviewed by } \\
\text { gynaecologic pathologist }\end{array}$ \\
\hline $\begin{array}{l}\text { Study of Epidemiology and } \\
\text { Risk Factors in Cancer } \\
\text { Heredity (Song et al, 2006) }\end{array}$ & SEA & $\begin{array}{l}\text { East Anglia } \\
\text { and West } \\
\text { Midlands, UK }\end{array}$ & 1998-2008 & $\begin{array}{l}\text { East Anglia and West Midlands Cancer } \\
\text { Registry }\end{array}$ & $\begin{array}{l}\text { Centralised review of } \\
\text { pathology reports by a } \\
\text { pathologist }\end{array}$ \\
\hline $\begin{array}{l}\text { Toronto Ovarian Cancer } \\
\text { Study (Narod et al, 1998) }\end{array}$ & TOC & $\begin{array}{l}\text { Ontario, } \\
\text { Canada }\end{array}$ & 1995-2003 & Ontario Cancer Registry & $\begin{array}{l}\text { Pathology reports and } \\
\text { histological slides reviewed by } \\
\text { a study pathologist }\end{array}$ \\
\hline $\begin{array}{l}\text { United Kingdom Ovarian } \\
\text { Cancer Population Study } \\
\text { (Balogun et al, 2011) }\end{array}$ & UKO & $\begin{array}{l}\text { England, } \\
\text { Wales and } \\
\text { Northern } \\
\text { Ireland, UK }\end{array}$ & $2006-2010$ & $\begin{array}{l}10 \text { major Gynecologic Oncology NHS } \\
\text { centers in England, Wales and Northern } \\
\text { Ireland; cancer registries; NHS Information } \\
\text { Centre for Health and Social Care } \\
\text { (England and Wales) and Central Services } \\
\text { Agency (Northern Ireland) }\end{array}$ & $\begin{array}{l}\text { Centralised review of } \\
\text { pathology reports by a } \\
\text { gynaecologic oncologist }\end{array}$ \\
\hline $\begin{array}{l}\text { Vancouver Ovarian Cancer } \\
\text { Study (Prentice et al, 2007; } \\
\text { Kobel et al, 2010b) }\end{array}$ & VAN & $\begin{array}{l}\text { British } \\
\text { Columbia, } \\
\text { Canada }\end{array}$ & $1984-2000$ & $\begin{array}{l}\text { Ovarian Cancer Registry serving British } \\
\text { Columbia, and the Cheryl Brown } \\
\text { Outcomes unit }\end{array}$ & $\begin{array}{l}\text { Histological review of all slides } \\
\text { by University of British } \\
\text { Columbia pathologists } \\
\text { supported by centralised } \\
\text { biomarker analysis }\end{array}$ \\
\hline
\end{tabular}

period $(P$ interaction with time $=0.01) \quad($ Table 4$)$. FOLR1 expression was associated with a $29 \%$ non-significant increased OS $(P=0.08)$ during the first year following diagnosis and a $50 \%$ non-significant decreased OS during the fourth year. The pattern of changing survival with increasing follow-up time, however, was most evident among patients with FIGO stage I/II tumours ( $P$ interaction with time $=0.02$ ). Among these patients, FOLR1 expression was associated with a 56\% significant increased OS during the first 2 years of follow-up only (HR: 0.44, 95\% CI: 0.20 $0.96, P=0.04)$. An interaction between FOLR1 expression and follow-up time was not observed with PFS.

Among 485 patients with HGSC in TCGA, FOLR1 mRNA upregulation was present in 93 patients (19\%). The associations between FOLR1 mRNA upregulation and survival in TCGA were similar to those observed in the OTTA data for HGSC. A significant interaction with follow-up time was seen for OS
$(P$ interaction with time $=0.02)$ (Table 5$)$. Following additional adjustment for platinum sensitivity and treatment response, FOLR1 mRNA upregulation was associated with a 52\% significant increased OS during the first 2 years of follow-up only (HR: 0.48, 95\% CI: $0.25-0.94, P=0.03$ ) (Table 5). Although most of these patients had FIGO stage III/IV tumours, the association did not strengthen when restricted to advanced stage tumours $(P=0.05)$. A non-significant interaction between FOLR1 mRNA upregulation and follow-up time was observed for PFS.

Association between FOLR1 expression in non-HGSC tumours and survival in OTTA. No significant interactions were found between FOLR1 expression and follow-up time for the other ovarian histological types. When stratified by stage, a nonsignificant decreased OS interval was observed among patients with CCC and FIGO stage I/II (HR: 1.62, 95\% CI: 0.97-2.71, 
Table 2. Number of patients with invasive ovarian carcinoma across studies and by histological type in OTTA

\begin{tabular}{|c|c|c|c|c|c|c|}
\hline $\begin{array}{l}\text { Study } \\
\text { abbreviation }\end{array}$ & $\begin{array}{c}\text { Total patients } \\
\mathbf{N}=\mathbf{2 8 0 1}\end{array}$ & $\begin{array}{c}\text { HGSC } \\
N=1507\end{array}$ & $\begin{array}{l}\text { LGSC } \\
N=91\end{array}$ & $\begin{array}{c}M C \\
N=193\end{array}$ & $\begin{array}{c}E C \\
N=564\end{array}$ & $\begin{array}{c}\mathrm{CCC} \\
N=446\end{array}$ \\
\hline $\mathrm{AOC}$ & 89 & 89 & 0 & 0 & 0 & 0 \\
\hline AOV & 209 & 0 & 0 & 18 & 95 & 96 \\
\hline BAV & 214 & 133 & 19 & 19 & 26 & 17 \\
\hline CAL & 68 & 63 & 5 & 0 & 0 & 0 \\
\hline HOP & 34 & 25 & 1 & 0 & 7 & 1 \\
\hline MAL & 245 & 117 & 12 & 21 & 66 & 29 \\
\hline MAY & 460 & 337 & 17 & 14 & 63 & 29 \\
\hline NOT & 196 & 106 & 9 & 16 & 39 & 26 \\
\hline SEA & 364 & 164 & 8 & 42 & 92 & 58 \\
\hline TOC & 160 & 50 & 0 & 20 & 45 & 45 \\
\hline UKO & 102 & 68 & 7 & 5 & 7 & 15 \\
\hline VAN & 660 & 355 & 13 & 38 & 124 & 130 \\
\hline
\end{tabular}

Table 3. Characteristics of patients with invasive ovarian carcinoma by histological type in OTTA

\begin{tabular}{|c|c|c|c|c|c|}
\hline Characteristic & $\begin{array}{c}\text { HGSC } \\
N=1507\end{array}$ & $\begin{array}{c}\text { LGSC } \\
N=91\end{array}$ & $\begin{array}{c}M C \\
N=193\end{array}$ & $\begin{array}{c}E C \\
N=564\end{array}$ & $\begin{array}{c}\mathrm{CCC} \\
N=446\end{array}$ \\
\hline Age at diagnosis, mean \pm s.d. & $61.1 \pm 11.2$ & $55.3 \pm 13.5$ & $55.5 \pm 13.9$ & $56.1 \pm 11.8$ & $57.4 \pm 11.5$ \\
\hline Total years followed ${ }^{a, b}$, mean \pm s.d. & $4.1 \pm 3.2$ & $5.8 \pm 4.1$ & $5.9 \pm 4.5$ & $6.9 \pm 4.4$ & $5.9 \pm 4.6$ \\
\hline Overall time to death ${ }^{\mathbf{b}}$, years, mean \pm s.d. & $3.2 \pm 2.3$ & $4.3 \pm 3.1$ & $2.6 \pm 2.5$ & $5.0 \pm 3.9$ & $3.5 \pm 3.2$ \\
\hline \multicolumn{6}{|l|}{ Vital status $^{\mathrm{b}}, N(\%)$} \\
\hline Alive & $421(29.6)$ & $41(48.2)$ & $114(64.0)$ & $371(70.5)$ & $239(56.2)$ \\
\hline Died & $1001(70.4)$ & $44(51.8)$ & $64(36.0)$ & $155(29.5)$ & $186(43.8)$ \\
\hline Overall time to progression ${ }^{a, b}$, years, mean \pm s.d. & $2.5 \pm 2.7$ & $3.6 \pm 4.1$ & $4.8 \pm 4.2$ & $5.9 \pm 4.2$ & $4.8 \pm 4.5$ \\
\hline \multicolumn{6}{|l|}{ Progression status ${ }^{\mathbf{b}}, \mathrm{N}(\%)$} \\
\hline Progression-free & $344(30.0)$ & $31(44.9)$ & $88(71.5)$ & $284(75.3)$ & $201(58.9)$ \\
\hline Progressed & $804(70.0)$ & $38(55.1)$ & $35(28.4)$ & $93(24.7)$ & $140(41.0)$ \\
\hline \multicolumn{6}{|l|}{ Stage $^{b}, N(\%)$} \\
\hline FIGO IA, IB, IC, II (localised) & $379(26.6)$ & $28(32.9)$ & $130(73.0)$ & $422(80.2)$ & $328(77.2)$ \\
\hline FIGO III, IV (distant) & $1030(72.4)$ & $58(65.9)$ & $34(19.1)$ & $88(16.7)$ & $82(19.3)$ \\
\hline Unknown & $13(0.9)$ & $1(1.1)$ & $14(7.9)$ & $16(3.0)$ & $15(3.5)$ \\
\hline \multicolumn{6}{|l|}{ Macroscopic residual disease ${ }^{b}, N(\%)$} \\
\hline No & $447(31.4)$ & $43(50.6)$ & $91(51.1)$ & $327(62.2)$ & $254(59.8)$ \\
\hline Yes & $634(45.6)$ & $24(28.2)$ & 29 (16.3) & $49(9.3)$ & $45(10.6)$ \\
\hline Unknown & $341(24.0)$ & $18(21.2)$ & $58(32.6)$ & $150(28.5)$ & $126(29.6)$ \\
\hline \multicolumn{6}{|l|}{ FOLR1 expression, $\mathbf{N}(\%)$} \\
\hline Absent/weak & $358(23.8)$ & $46(51.0)$ & $171(88.6)$ & $398(70.6)$ & $305(68.3)$ \\
\hline Strong $1-50 \%$ & $371(24.6)$ & $20(22.0)$ & $12(6.2)$ & $100(17.7)$ & $88(19.7)$ \\
\hline Strong membranous $>50 \%$ & $282(18.7)$ & $15(16.5)$ & $6(3.1)$ & $44(7.8)$ & $29(6.5)$ \\
\hline Strong cytoplasmic 50-95\% & 367 (24.4) & $8(8.8)$ & $2(1.0)$ & $17(3.0)$ & $21(4.7)$ \\
\hline Strong cytoplasmic $>95 \%$ & $129(8.6)$ & $2(2.2)$ & $2(1.0)$ & $5(0.9)$ & $3(0.7)$ \\
\hline
\end{tabular}

$P=0.07$ ) (Table 6), whereas a 57\% significant decreased PFS interval was seen among patients with CCC overall (HR: 1.57, 95\% CI: $1.06-2.34, \quad P=0.02)$, which was more pronounced among patients with FIGO stage I/II tumours (HR: 1.89, 95\% CI: $1.10-3.25, P=0.02$ ) (Table 7). No other associations were found.

\section{DISCUSSION}

Our investigation showed that the association between FOLR1 expression or FOLR1 mRNA upregulation among 1900 patients with HGSC from two independent data sets changed significantly during the years following diagnosis. In OTTA, this translated to an increase in OS by $56 \%$ among women with FOLR1-positive HGSC in the first 2 years of follow-up only and a decrease in PFS by $89 \%$ among women with FOLR1-positive CCC irrespective of follow-up time. Both findings were more pronounced among patients with FIGO stage I/II tumours.

Both our OTTA data and those we analysed from TCGA provide evidence, for the first time, that the association between FOLR1 expression and OS in HGSC changes with the duration of follow-up regardless of whether FOLR1 was measured as protein or mRNA. Previous studies reported either unfavourable prognosis 
The association between FOLR1 protein expression and decrease in PFS interval in patients with CCC and, specifically FIGO stage I/II tumours, is potentially interesting and will require independent confirmation. FIGO stage I/II tumours comprise the majority of CCC (almost $80 \%$ of CCC and 12\% of all patients in our study) and their optimal management represents a clinical dilemma, because $\sim 20 \%$ of patients relapse and are resistant to platinum-based chemotherapy (Kobel et al, 2010a; Anglesio et al, 2011). Existing clinical trials that are testing therapies to FOLR1 expression in ovarian carcinoma are comprised mostly of HGSC and one reported a favourable outcome among patients with platinum-resistant recurrent ovarian carcinoma (Naumann et al, 2013), which is a clinical profile similar to CCC. Interestingly, that study (Naumann et al, 2013) included eight patients with CCC (seven in the vintafolide arm). It remains to be evaluated whether targeting therapies specifically to FOLR1 in patients with CCC and FIGO stage I/II tumours improves their survival.

We observed that FOLR1 protein was expressed in $76 \%$ of HGSC, which agrees with a recent estimate of prevalence by Crane et al (2012) of $82 \%$ among 210 patients with HGSC. Further, only $\sim 30 \%$ of CCC and EC, and $11 \%$ of MC were positive for FOLR1. These estimates are lower than those reported previously and may be from the much smaller sample sizes evaluated in studies of HGSC $(N=36-73)$ (Kelemen et al, 2005; Despierre et al, 2013; O'Shannessy et al, 2013) and of other histological types (Kalli et al, 2008; Crane et al, 2012). We also observed FOLR1 expression in normal fallopian tube tissue samples, which is increasingly accepted as the cell of origin for most HGSC (Piek et al, 2001; Crum et al, 2007). Others also reported strong FOLR1 expression in normal fallopian tube (Veggian et al, 1989; O’Shannessy et al, 2013), postulating that FOLR1 tumour expression is maintained from cell type-oforigin (O'Shannessy et al, 2013). However, at least two previous studies found strong FOLR1 expression in normal ovarian surface epithelium (Wu et al, 1999; Kelemen et al, 2005), including one that prospectively collected ovarian surface epithelial samples from healthy postmenopausal women undergoing oophorectomy (Kelemen et al, 2005). Given the difficulty to obtain viable normal ovarian surface epithelium, we question whether earlier studies (Veggian et al, 1989; Ross et al, 1994; Parker et al, 2005) found low expression in ovarian stroma rather than epithelium.

There are several strengths to this investigation. We showed the novel result that the association between FOLR1 expression and OS changes with the duration of follow-up and with histological cell type. Our evaluation is the largest assembly of an unselected sample of HGSC and other ovarian carcinoma types. We performed a centralised IHC assay with excellent inter-observer reproducibility that correlated reasonably well with FOLR1 mRNA expression level among a subset of patients in our sample. Harmonisation of clinical variables contributed to robust statistical analysis and control for potential confounding. We also leveraged TCGA data to evaluate the association with HGSC in an independent data set and, although the direction and magnitude of the associations were similar between OTTA and TCGA samples, TCGA had too few tumours with FIGO stage I/II to evaluate.

In summary, we found that FOLR1 protein was widely expressed in patients with HGSC in OTTA and that expression was associated with increased OS in the first 2 years following diagnosis. The association with clinical outcome in CCC was opposite to that seen for HGSC with a decreased progression-free interval observed for FOLR1-positive CCC. Both findings were more pronounced among patients with FIGO stage I/II tumours. Our study highlights the need to evaluate FOLR1-targeted therapy outcomes by histological type, stage and time following diagnosis if FOLR1 is to be used as a target for therapeutic intervention.

\section{ACKNOWLEDGEMENTS}

We wish to thank all of the patients, study centers and personnel who participated in this study. We gratefully acknowledge the contributions of the AOCS Group (http://www.aocstudy.org) (AOC); Mie Konno, Michelle Darago, Faye Chambers, the Tom Baker Cancer Centre Translational Laboratories (AOV); Karin Goodman, Ashley Pitzer, Mayo Clinic Medical Genome Facility (MAY, MAC); Kristy Angell, SEARCH team, the Human Research Tissue Bank at Addenbrooke's Hospital that is supported by the NIHR Cambridge Biomedical Research Centre (SEA); Ian Jacobs, Eva Wozniak, Andy Ryan, Jeremy Ford, Nayala Balogun (UKO); and the Cheryl Brown Ovarian Cancer Outcomes Unit (VAN). The results published here are in part based upon data generated by The Cancer Genome Atlas Project established by the National Cancer Institute and National Human Genome Research Institute. Information about TCGA and the investigators and institutions that constitute the TCGA research network can be found at http:// cancergenome.nih.gov/. This manuscript is dedicated to the memory of Barton A Kamen for his pioneering work in folatebinding proteins and anti-folate pharmacology. This work was supported by the US Department of Defense (DAMD17-01-10729), Cancer Council Victoria, Queensland Cancer Fund, Cancer Council New South Wales, Cancer Council South Australia, Cancer Foundation of Western Australia, Cancer Council Tasmania and National Health and Medical Research Council of Australia (NHMRC, Grants 400413 and 400281) (AOC); the Canadian Institutes for Health Research (MOP-86727) (AOV); Calgary Laboratory Services (RS10-533) (CAL); the National Institutes of Health (R01CA61107), Danish Cancer Society (research grant 94222 52) and Mermaid I project (MAL); National Institutes of Health (R01CA122443, P50CA136393), Mayo Foundation and Fred C. and Katherine B. Andersen Foundation (MAY, MAC); Cancer Research UK (C490/A10119, C490/A10124), National Institute for Health Research (NIHR) Cambridge Biomedical Research Centre, Cambridge Experimental Cancer Medicine Centre (SEA); Eve Appeal (Oak Foundation), and NIHR University College London Hospitals Biomedical Research Centre (UKO); British Columbia Cancer Foundation, the Carraressi Foundation through donations to the Vancouver General Hospital and University of British Columbia Hospital Foundation (VAN). BG was supported by NHMRC and the Cancer Institute of NSW (CINSW), AdeF was supported by the University of Sydney Cancer Research Fund, and CINSW through the Sydney-West Translational Cancer Research Centre. LEK was supported by a Canadian Institutes for Health Research Investigator award MSH-87734.

\section{CONFLICT OF INTEREST}

The authors declare no conflict of interest.

\section{AUTHOR CONTRIBUTIONS}

MK and LEK designed the overall study and oversaw statistical analysis. SJR, DGH, MK and LEK obtained financial support. SJR and MPI coordinated the OTTA studies database. MK and JM reviewed histological slides. $\mathrm{AD}, \mathrm{BG}$ and $\mathrm{SEJ}$ harmonised the clinical variables. MK, BAC, PDPP, SD, DDB, KO, UM, CM, SL, WB, LS, MWB, AH, FCT, AH, DLW, MSA, EH, AJ, CH, KRK, BLF, GLK, ZCF, RAV, SL, SC, GN, PG, AG-M, SAG, EB, MW, BR, MB, HM, AO, PS, MJ-L, KED, JA, MM, JMK, HS, CE, AD, GC-T, SF, BG, SEJ, JG, LG, ELG, SKK, DGH, PAF, KBM, JDB and LEK coordinated contributing studies. MK, JDB and LEK drafted the manuscript, and all authors contributed to the final draft. 


\section{REFERENCES}

Anglesio MS, Carey MS, Kobel M, Mackay H, Huntsman DG (2011) Clear cell carcinoma of the ovary: a report from the first Ovarian Clear Cell Symposium, June 24th, 2010. Gynecol Oncol 121(2): 407-415.

Armstrong DK, White AJ, Weil SC, Phillips M, Coleman RL (2013) Farletuzumab (a monoclonal antibody against folate receptor alpha) in relapsed platinum-sensitive ovarian cancer. Gynecol Oncol 129(3): $452-458$.

Balogun N, Gentry-Maharaj A, Wozniak EL, Lim A, Ryan A, Ramus SJ, Ford J, Burnell M, Widschwendter M, Gessler SF, Gayther SA, Jacobs IJ, Menon U (2011) Recruitment of newly diagnosed ovarian cancer patients proved challenging in a multicentre biobanking study. J Clin Epidemiol 64(5): 525-530.

Bromley AB, Altman AD, Chu P, Nation JG, Nelson GS, Ghatage P, Kalloger SE, Han G, Kobel M (2012) Architectural patterns of ovarian/ pelvic high-grade serous carcinoma. Int J Gynecol Pathol 31(5): 397-404

Cerami E, Gao J, Dogrusoz U, Gross BE, Sumer SO, Aksoy BA, Jacobsen A, Byrne CJ, Heuer ML, Larsson E, Antipin Y, Reva B, Goldberg AP, Sander C, Schultz N (2012) The cBio cancer genomics portal: an open platform for exploring multidimensional cancer genomics data. Cancer Discov 2(5): 401-404.

Chen YL, Chang MC, Huang CY, Chiang YC, Lin HW, Chen CA, Hsieh CY, Cheng WF (2012) Serous ovarian carcinoma patients with high alpha-folate receptor had reducing survival and cytotoxic chemo-response. Mol Oncol 6(3): 360-369.

Crane LM, Arts HJ, van Oosten M, Low PS, van der Zee AG, van Dam GM, Bart J (2012) The effect of chemotherapy on expression of folate receptor-alpha in ovarian cancer. Cell Oncol (Dordr) 35(1): 9-18.

Crum CP, Drapkin R, Miron A, Ince TA, Muto M, Kindelberger DW, Lee Y (2007) The distal fallopian tube: a new model for pelvic serous carcinogenesis. Curr Opin Obstet Gynecol 19(1): 3-9.

Despierre E, Lambrechts S, Leunen K, Berteloot P, Neven P, Amant F, O'Shannessy DJ, Somers EB, Vergote I (2013) Folate receptor alpha (FRA) expression remains unchanged in epithelial ovarian and endometrial cancer after chemotherapy. Gynecol Oncol 130(1): 192-199.

Ebel W, Routhier EL, Foley B, Jacob S, McDonough JM, Patel RK, Turchin HA, Chao Q, Kline JB, Old LJ, Phillips MD, Nicolaides NC, Sass PM, Grasso L (2007) Preclinical evaluation of MORAb-003, a humanized monoclonal antibody antagonizing folate receptor-alpha. Cancer Immun 7: 6.

Glud E, Kjaer SK, Thomsen BL, Hogdall C, Christensen L, Hogdall E, Bock JE, Blaakaer J (2004) Hormone therapy and the impact of estrogen intake on the risk of ovarian cancer. Arch Intern Med 164(20): 2253-2259.

Goode EL, Chenevix-Trench G, Hartmann LC, Fridley BL, Kalli KR, Vierkant RA, Larson MC, White KL, Keeney GL, Oberg TN, Cunningham JM, Beesley J, Johnatty SE, Chen X, Goodman KE, Armasu SM, Rider DN, Sicotte H, Schmidt MM, Elliott EA, Hogdall E, Kjaer SK, Fasching PA, Ekici AB, Lambrechts D, Despierre E, Hogdall C, Lundvall L, Karlan BY, Gross J, Brown R, Chien J, Duggan DJ, Tsai YY, Phelan CM, Kelemen LE Peethambaram PP, Schildkraut JM, Shridhar V, Sutphen R, Couch FJ, Sellers TA (2011) Assessment of hepatocyte growth factor in ovarian cancer mortality. Cancer Epidemiol Biomarkers Prev 20(8): $1638-1648$.

He W, Kularatne SA, Kalli KR, Prendergast FG, Amato RJ, Klee GG, Hartmann LC, Low PS (2008) Quantitation of circulating tumor cells in blood samples from ovarian and prostate cancer patients using tumor-specific fluorescent ligands. Int J Cancer 123(8): 1968-1973.

Hein A, Thiel FC, Bayer CM, Fasching PA, Haberle L, Lux MP, Renner SP, Jud SM, Schrauder MG, Muller A, Wachter D, Strehl J, Hartmann A, Beckmann MW, Rauh C (2013) Hormone replacement therapy and prognosis in ovarian cancer patients. Eur J Cancer Prev 22(1): 52-58.

Hosmer DW, Lameshow SL (1999) Applied Survival Analysis: Regression Modeling of Time to Event Data. John Wiley \& Sons Inc: New York, NY, USA.

Kalli KR, Oberg AL, Keeney GL, Christianson TJ, Low PS, Knutson KL, Hartmann LC (2008) Folate receptor alpha as a tumor target in epithelial ovarian cancer. Gynecol Oncol 108(3): 619-626.

Kamen BA, Smith AK (2012) Farletuzumab, an anti-folate receptor alpha antibody, does not block binding of folate or anti-folates to receptor nor does it alter the potency of anti-folates in vitro. Cancer Chemother Pharmacol 70(1): 113-120.
Kane MA, Elwood PC, Portillo RM, Antony AC, Najfeld V, Finley A, Waxman S, Kolhouse JF (1988) Influence on immunoreactive folatebinding proteins of extracellular folate concentration in cultured human cells. J Clin Invest 81(5): 1398-1406.

Kelemen LE (2006) The role of folate receptor alpha in cancer development, progression and treatment: cause, consequence or innocent bystander? Int J Cancer 119(2): 243-250.

Kelemen LE, Kobel M, Chan A, Taghaddos S, Dinu I (2013) Differentially methylated loci distinguish ovarian carcinoma histological types: evaluation of a DNA methylation assay in FFPE tissue. Biomed Res Int 2013: 815894

Kelemen LE, Sellers TA, Keeney GL, Lingle WL (2005) Multivitamin and alcohol intake and folate receptor alpha expression in ovarian cancer. Cancer Epidemiol Biomarkers Prev 14(9): 2168-2172.

Knutson KL, Krco CJ, Erskine CL, Goodman K, Kelemen LE, Wettstein PJ, Low PS, Hartmann LC, Kalli KR (2006) T-cell immunity to the folate receptor alpha is prevalent in women with breast or ovarian cancer. J Clin Oncol 24(26): 4254-4261.

Kobel M, Kalloger SE, Boyd N, McKinney S, Mehl E, Palmer C, Leung S, Bowen NJ, Ionescu DN, Rajput A, Prentice LM, Miller D, Santos J, Swenerton K, Gilks CB, Huntsman D (2008) Ovarian carcinoma subtypes are different diseases: implications for biomarker studies. PLoS Med 5(12): e232.

Kobel M, Kalloger SE, Lee S, Duggan MA, Kelemen LE, Prentice L, Kalli KR, Fridley BL, Visscher DW, Keeney GL, Vierkant RA, Cunningham JM, Chow C, Ness RB, Moysich K, Edwards R, Modugno F, Bunker C, Wozniak EL, Benjamin E, Gayther SA, Gentry-Maharaj A, Menon U, Gilks CB, Huntsman DG, Ramus SJ, Goode EL (2013) Biomarker-based ovarian carcinoma typing: a histologic investigation in the ovarian tumor tissue analysis consortium. Cancer Epidemiol Biomarkers Prev 22(10): 1677-1686.

Kobel M, Kalloger SE, Santos JL, Huntsman DG, Gilks CB, Swenerton KD (2010a) Tumor type and substage predict survival in stage I and II ovarian carcinoma: insights and implications. Gynecol Oncol 116(1): 50-56.

Kobel M, Reuss A, Bois A, Kommoss S, Kommoss F, Gao D, Kalloger SE, Huntsman DG, Gilks CB (2010b) The biological and clinical value of p53 expression in pelvic high-grade serous carcinomas. J Pathol 222(2): 191-198.

Konner JA, Bell-McGuinn KM, Sabbatini P, Hensley ML, Tew WP, Pandit-Taskar N, Vander Els N, Phillips MD, Schweizer C, Weil SC, Larson SM, Old LJ (2010) Farletuzumab, a humanized monoclonal antibody against folate receptor alpha, in epithelial ovarian cancer: a phase I study. Clin Cancer Res 16(21): 5288-5295.

Leamon CP, Reddy JA (2004) Folate-targeted chemotherapy. Adv Drug Deliv Rev 56(8): 1127-1141.

Lo-Ciganic WH, Zgibor JC, Bunker CH, Moysich KB, Edwards RP, Ness RB (2012) Aspirin, nonaspirin nonsteroidal anti-inflammatory drugs, or acetaminophen and risk of ovarian cancer. Epidemiology 23(2): 311-319.

McShane LM, Altman DG, Sauerbrei W, Taube SE, Gion M, Clark GM (2005) REporting recommendations for tumour MARKer prognostic studies (REMARK). Br J Cancer 93(4): 387-391.

Merritt MA, Green AC, Nagle CM, Webb PM (2008) Talcum powder, chronic pelvic inflammation and NSAIDs in relation to risk of epithelial ovarian cancer. Int J Cancer 122(1): 170-176.

Miotti S, Bagnoli M, Tomassetti A, Colnaghi MI, Canevari S (2000) Interaction of folate receptor with signaling molecules lyn and G(alpha) (i-3) in detergent-resistant complexes from the ovary carcinoma cell line IGROV1. J Cell Sci 113(Pt 2): 349-357.

Narod SA, Risch H, Moslehi R, Dorum A, Neuhausen S, Olsson H, Provencher D, Radice P, Evans G, Bishop S, Brunet JS, Ponder BA (1998) Oral contraceptives and the risk of hereditary ovarian cancer. Hereditary Ovarian Cancer Clinical Study Group. $N$ Engl J Med 339(7): 424-428.

Naumann RW, Coleman RL, Burger RA, Sausville EA, Kutarska E, Ghamande SA, Gabrail NY, Depasquale SE, Nowara E, Gilbert L, Gersh RH, Teneriello MG, Harb WA, Konstantinopoulos PA, Penson RT, Symanowski JT, Lovejoy CD, Leamon CP, Morgenstern DE, Messmann RA (2013) PRECEDENT: a randomized phase II trial comparing vintafolide (EC145) and pegylated liposomal doxorubicin (PLD) in combination versus PLD alone in patients with platinumresistant ovarian cancer. J Clin Oncol 31(35): 4400-4406.

O'Shannessy DJ, Somers EB, Smale R, Fu YS (2013) Expression of folate receptor-alpha (FRA) in gynecologic malignancies and its relationship to the tumor type. Int J Gynecol Pathol 32(3): 258-268. 
Parker N, Turk MJ, Westrick E, Lewis JD, Low PS, Leamon CP (2005) Folate receptor expression in carcinomas and normal tissues determined by a quantitative radioligand binding assay. Anal Biochem 338(2): 284-293.

Piek JM, van Diest PJ, Zweemer RP, Jansen JW, Poort-Keesom RJ, Menko FH, Gille JJ, Jongsma AP, Pals G, Kenemans P, Verheijen RH (2001) Dysplastic changes in prophylactically removed Fallopian tubes of women predisposed to developing ovarian cancer. J Pathol 195(4): 451-456.

Prentice LM, Klausen C, Kalloger S, Kobel M, McKinney S, Santos JL, Kenney C, Mehl E, Gilks CB, Leung P, Swenerton K, Huntsman DG, Aparicio SA (2007) Kisspeptin and GPR54 immunoreactivity in a cohort of 518 patients defines favourable prognosis and clear cell subtype in ovarian carcinoma. BMC Med 5: 33.

Ross JF, Chaudhuri PK, Ratnam M (1994) Differential regulation of folate receptor isoforms in normal and malignant tissues in vivo and in established cell lines. Physiologic and clinical implications. Cancer 73(9): 2432-2443.

Shah SP, Kobel M, Senz J, Morin RD, Clarke BA, Wiegand KC, Leung G, Zayed A, Mehl E, Kalloger SE, Sun M, Giuliany R, Yorida E, Jones S, Varhol R, Swenerton KD, Miller D, Clement PB, Crane C, Madore J, Provencher D, Leung P, DeFazio A, Khattra J, Turashvili G, Zhao Y, Zeng T, Glover JN, Vanderhyden B, Zhao C, Parkinson CA, Jimenez-Linan M, Bowtell DD, Mes-Masson AM, Brenton JD, Aparicio SA, Boyd N, Hirst M, Gilks CB, Marra M, Huntsman DG (2009) Mutation of FOXL2 in granulosa-cell tumors of the ovary. $N$ Engl J Med 360(26): 2719-2729.

Sieh W, Kobel M, Longacre TA, Bowtell DD, Defazio A, Goodman MT, Hogdall E, Deen S, Wentzensen N, Moysich KB, Brenton JD, Clarke BA, Menon U, Gilks CB, Kim A, Madore J, Fereday S, George J, Galletta L, Lurie G, Wilkens LR, Carney ME, Thompson PJ, Matsuno RK, Kjaer SK, Jensen A, Hogdall C, Kalli KR, Fridley BL, Keeney GL, Vierkant RA, Cunningham JM, Brinton LA, Yang HP, Sherman ME, Garcia-Closas M, Lissowska J, Odunsi K, Morrison C, Lele S, Bshara W, Sucheston L, Jimenez-Linan M, Driver K, Alsop J, Mack M, McGuire V, Rothstein JH, Rosen BP, Bernardini MQ, Mackay H, Oza A, Wozniak EL, Benjamin E, Gentry-Maharaj A, Gayther SA, Tinker AV, Prentice LM, Chow C, Anglesio MS, Johnatty SE, Chenevix-Trench G, Whittemore AS, Pharoah PD, Goode EL, Huntsman DG, Ramus SJ (2013) Hormonereceptor expression and ovarian cancer survival: an Ovarian Tumor Tissue Analysis consortium study. Lancet Oncol 14(9): 853-862.
Soegaard M, Jensen A, Hogdall E, Christensen L, Hogdall C, Blaakaer J, Kjaer SK (2007) Different risk factor profiles for mucinous and nonmucinous ovarian cancer: results from the Danish MALOVA study. Cancer Epidemiol Biomarkers Prev 16(6): 1160-1166.

Song H, Ramus SJ, Quaye L, DiCioccio RA, Tyrer J, Lomas E, Shadforth D, Hogdall E, Hogdall C, McGuire V, Whittemore AS, Easton DF, Ponder BA, Kjaer SK, Pharoah PD, Gayther SA (2006) Common variants in mismatch repair genes and risk of invasive ovarian cancer. Carcinogenesis 27(11): 2235-2242.

Spannuth WA, Sood AK, Coleman RL (2010) Farletuzumab in epithelial ovarian carcinoma. Expert Opin Biol Ther 10(3): 431-437.

The Cancer Genome Atlas Research Network (2011) Integrated genomic analyses of ovarian carcinoma. Nature 474(7353): 609-615.

van Dam GM, Themelis G, Crane LM, Harlaar NJ, Pleijhuis RG, Kelder W, Sarantopoulos A, de Jong JS, Arts HJ, van der Zee AG, Bart J, Low PS, Ntziachristos V (2011) Intraoperative tumor-specific fluorescence imaging in ovarian cancer by folate receptor-alpha targeting: first in-human results. Nat Med 17(10): 1315-1319.

Veggian R, Fasolato S, Menard S, Minucci D, Pizzetti P, Regazzoni M, Tagliabue E, Colnaghi MI (1989) Immunohistochemical reactivity of a monoclonal antibody prepared against human ovarian carcinoma on normal and pathological female genital tissues. Tumori 75(5): 510-513.

Walters CL, Arend RC, Armstrong DK, Naumann RW, Alvarez RD (2013) Folate and folate receptor alpha antagonists mechanism of action in ovarian cancer. Gynecol Oncol 131(2): 493-498.

Williams E, Martin S, Moss R, Durrant L, Deen S (2012) Co-expression of VEGF and CA9 in ovarian high-grade serous carcinoma and relationship to survival. Virchows Arch 461(1): 33-39.

Wu M, Gunning W, Ratnam M (1999) Expression of folate receptor type alpha in relation to cell type, malignancy, and differentiation in ovary, uterus, and cervix. Cancer Epidemiol Biomarkers Prev 8(9): 775-782.

This work is published under the standard license to publish agreement. After 12 months the work will become freely available and the license terms will switch to a Creative Commons AttributionNonCommercial-Share Alike 3.0 Unported License. 